\title{
Teaching at primary healthcare services within the Brazilian National Health System (SUS) in Brazilian healthcare professionals' training*
}

\author{
Ramona Fernanda Ceriotti Toassi \\ Alexandre Baumgarten ${ }^{2}$ \\ Cristine Maria Warmling ${ }^{3}$ \\ Eloá Rossoni ${ }^{4}$ \\ Arisson Rocha da Rosa ${ }^{5}$ \\ Sonia Maria Blauth Slavutzky ${ }^{6}$
}

TOASSI, R.F.C. et al. O ensino nos serviços de atenção primária do Sistema Único de Saúde (SUS) na formação de profissionais de saúde no Brasil. Interface (Botucatu), v.17, n.45, p.385-92, abr./jun. 2013.

The aim of this study was to analyze the role of teaching at primary healthcare services within the Brazilian National Health System (SUS) in dentists' training, at a public university in the south of Brazil. A qualitative methodological approach (case study) was used. Interviews were conducted with 12 dentistry students, six dentists who were preceptors working in public primary healthcare services and three teachers connected with this curricular training. Our findings showed that the curricular training in SUS primary healthcare services had an impact on the dentists' education through establishment of bonds, autonomy in problem-solving and multiprofessional teamwork. It was seen that they learned about how healthcare services function, about healthcare and about development of cultural competence. There is a need to maintain constant questioning regarding these practices, and to ensure the presence of infrastructure and qualified professionals for teaching at these services.

Keywords: Dentist' education. Primary healthcare. Health services. Curriculum. Qualitative research.
O objetivo desse estudo foi analisar o papel do ensino nos serviços de atenção primária do Sistema Único de Saúde (SUS) para a formação do cirurgião-dentista em uma universidade pública no sul do Brasil. A abordagem metodológica foi qualitativa (estudo de caso), realizando-se entrevistas com 12 estudantes de Odontologia, seis preceptores cirurgiões-dentistas com atuação nos serviços públicos de atenção primária e três professores vinculados ao estágio curricular. Os achados mostraram que o estágio curricular nos serviços de atenção primária do SUS impactou na formação do cirurgião-dentista por meio do estabelecimento de vínculos, autonomia na resolução de problemas e trabalho em equipe multiprofissional. Foram evidenciadas aprendizagens sobre funcionamento dos serviços de saúde, cuidado em saúde e desenvolvimento de competência cultural. Há necessidade da problematização permanente sobre as práticas e que se assegure infraestrutura e profissionais qualificados para o ensino nos serviços.

Palavras-chave: Educação em Odontologia. Atenção primária à saúde. Serviços de saúde. Currículo. Pesquisa qualitativa.

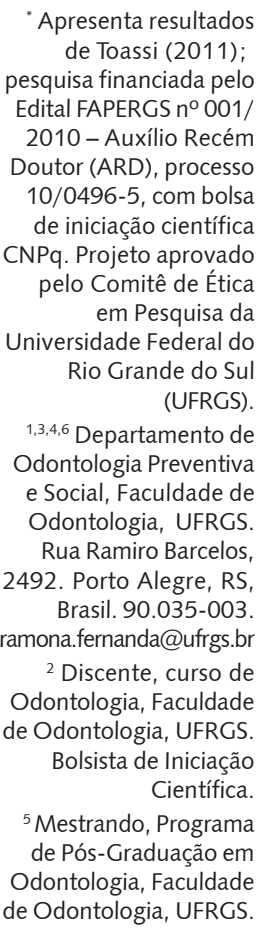

"Apresenta resultados de Toassi (2011); Edital FAPERGS n० 001/ 2010 - Auxílio Recém Doutor (ARD), processo 10/0496-5, com bolsa m Pesquisa da dade Federal do de do Sul

dontologia Preventiva

Social, Faculdade de dontologia, UFRGS. Brasil. 90.035-003. Iniciação Prontífica. Odontologia, Faculdade de Odontologia, UFRGS 


\section{Introduction}

Dental teaching was established in Brazil in the XIX century, and since its initial phase it was characterized by autonomy in relation to the medical teaching. Another aspect was that the curricula design emphasized dental techniques, but was limited concerning the development of knowledge on social aspects of health and oral diseases. This was a worldwide hegemonic trend at the time. These events greatly shaped the contemporary dental education, as well as the practice developed by the providers (Warmling, Marzola, Botazzo, 2012).

During the first decade of the XXI century, however, the curricula of dental undergraduate courses in Brazil are being reformulated to redirect the process of dental education (Toassi et al., 2012). The national curriculum guidelines (Brasil, 2002), adopted since 2002 by dental courses in the country, evidence transformations in dental practice stemming from various directions. These are events that have been manifesting worldwide since at least the 1980s and originated from the social, economic, and political fields, but mainly from the striking changes that occurred in the oral diseases demography and epidemiology.

Some assumptions stand out in the shaping of the new education standards for Brazilian dentists. The rate of dental caries has decreased due to the exposure to the preventive effects of fluorides; there have been marking changes in the self-employment working standards of dental providers in the country; and there is a high number of dentists available on the market. On the other hand, there is a significant contingent of vulnerable population groups whose access to dental services is still difficult (Moysés, 2004; Kress Junior, 1995).

The challenge for higher dental education institutions in Brazil has been, therefore, to adapt their curricula to the demands of the new professional paradigms. Amongst other aspects, the curricula must develop a professional profile with skills and competencies aimed at the work within the public health system, which currently is a potential employer for dentists (Morita, Haddad, Araújo, 2010). The expansion of the public dental services is gradually enhancing the insertion of dentistry within SUS (Pucca Junior, Lucena, Cawahisa, 2010). In Brazil, as well as in other countries, health care services have been prioritized in the curricula of dental courses as venues for education (Davidson et al., 2011; Hood, 2009; Holbrook et al., 2008; Elkind, 2002). The service-learning is a structured learning experience that combines community service with preparation and reflection (Yoder, 2006) and has become an axis for the change process in the professional education.

A nationwide study on the assessment of curricular reform experiences was conducted by the Brazilian Association of Dental Teaching from 2005 to 2006. Workshops were developed in 18 Brazilian dental schools in order to check for curricular changes. Amongst other results, the analysis of the workshops showed a persistent resistance regarding traditional conceptions on how the professional practice model should be (Zilbovicius et al., 2011). Focal studies must be conducted in order to understand how the pedagogical, technical, and political variables are involved in the changes undertaken by the schools.

The School of Dentistry of the Federal University of Rio Grande do Sul is a traditional Brazilian dental teaching public institution, being the third one created in the country. The school is over 120 years old, standing out in the national scenario due to the curricular changes that have taken place since 2005. One of the striking features which directed the reorganization of its curriculum was the enhancement of the integration of the academic activities with the world of work at the Brazilian National Health System (SUS). This experience needs to be studied in depth.

Such concerns guided this study, aimed to analyze the role played by the service-learning in Unified Health System (SUS) primary health care as a means for the education of dentists in a public university in the south of Brazil.

\section{Methodology}

The case study under a qualitative analysis perspective (Yin, 2010) was the method used in this research. The methodological choice for the qualitative approach was justified taking into consideration 
that its design allows the use of multiple information sources (Minayo, 2007), aiming to 'create a chain of relevant evidences' on the role of the service-learning program for the education of dental students, its pedagogical dynamics, and its relationship with the health care system.

Since 2005, the Federal University of Rio Grande do Sul/Brazil has progressively implemented, during the senior year ( $9^{\text {th }}$ and $10^{\text {th }}$ semester), a service-learning program within the practice facilities of SUS. The total workload of the program consists of 930 hours and is regulated by specific federal legislation (Brasil, 2008).

The focus of this research is the service-learning program that takes place during the $9^{\text {th }}$ semester of the course, in a total of 465 hours per semester, being developed in Primary Health Care Units. These units are responsible, under the scope of SUS, for providing primary health care in the municipality of Porto Alegre, Brazil. Each facility chosen to offer the service-learning program receives up to two dental students. The preceptor, who is responsible for the follow up and guidance of the students, is also the dentist who works in the health care service. The proposal of the service-learning program is based on the Problem-Based Learning (PBL) pedagogical method (Polyzois, Claffey, Mattheos, 2010).

Data for this study was produced by semi-structured interviews. The participants were undergraduate dental students, preceptors who were dentists of SUS, and teachers. All participants signed an informed consent form. The interviews were conducted individually by a single interviewer who followed a pretested script. Guiding questions: education level at the moment of knowing about service-learning/ feedback from others about service-learning; coming to the service/expectations regarding servicelearning; to feel prepared to work in primary care; relationship between the health team and the undergraduate dental student; positive changes of the service-learning to the service itself; servicelearning program and health care; activities carried out in the health service; role of the preceptor, feelings regarding service-learning program/gains with service-learning in the primary care service; impacts of service-learning on the education of dentists; relationship between the service-learning program, the curriculum, and the University. The interviews were recorded by audio equipment and fully transcribed. All transcriptions were returned to the interviewees, who read them to check if they agreed with the presented ideas; if considered necessary, they could add complementary information to the reports.

The subjects of this research were selected intentionally, taking into consideration the proposed objective. The students should have concluded the service-learning program in primary care. The criterion for the selection of preceptors and teachers was that they should be working with service-learning programs for at least one year. Saturation was the selected sampling method (Strauss, Corbin, 2008). A total of 21 people were interviewed: 12 senior dental students, six preceptors who were dentists of SUS, and three teachers from the School of Dentistry who were linked to the service-learning program.

The content analysis method (Bardin, 2011) was used to interpret the produced data.

The study was approved by the Ethics in Research Committee of the University.

\section{Results and discussion}

Based on the interpretation of the categories, four major thematic blocks were structured with the objective of organizing the discussion and theorization.

\section{Service-learning programs and social representations}

The beginning of the service-learning period in the primary health care made undergraduate dental students feel apprehensive. Their perceptions regarding the working conditions they would face were marked by the idea of an existing precarious situation in public services.

"I used to hear sort of that idea we all had about the service-learning. That public health centers weren't any good, that they were far, didn't have the necessary materials, that no 
one liked them, that it was a nuisance to everyone, that no one wanted to have to experience this" [...]. (Student 3)

This impression was also perceived by preceptors and teachers of the service-learning. "The students arrive highly technically prepared, but all sharing the common idea that everything is horrible there $[\ldots]^{\prime \prime}$. (Teacher 1)

Contradicting all negative expectations before the beginning of the service-learning experiences, the arrival at the services was marked, in general, by surprise when facing the reality they encountered. The students were positively surprised by the physical structure and the work developed in primary care. "[...] I was really surprised, it wasn't what I expected to find, I had an idea from what I had seen on TV, that there were long lines and lots of people in waiting rooms". (Student 12)

In another Brazilian study on dental service-learning programs, it was also observed that one of the big surprises of the students was to find, contrary to what they expected, an organized public service that works, serves the population, and has dental supplies and equipments of quality (Santa-Rosa, Vargas, Ferreira, 2007).

The social representations theory supported the analysis of the data found. Authors define the social representations as a pragmatic thinking that results from experience, beliefs, and information exchange in the daily lives of human beings. They take form as 'common sense theories', indicating how one is interpreting and interacting with the social reality (Jodelet, 2001; Spink, 1993). The reports of the students on their expectations regarding the service-learning program expose the social representations of the population concerning SUS. In a study on the perceptions of the workers of SUS, it was concluded that the creation/transformation of the social representations regarding the system is still taking place, however not in a naturalized fashion, but through multiple tensions (Oliveira et al., 2008).

The conflicts produced by the program's experiences are related to the course's current technical, pedagogical, and political process, as well as to the health system itself. Students who had been involved in activities in SUS prior to curricular service learning displayed more skills in dealing with the reality of the services. "It was of no surprise when I first arrived at the service-learning program. My first contact was with PET-Saúde, when I was (more or less) in my fifth semester [...]" (Student 2). The Education through Work in Health Program (PET-Saúde) is promoted by the Health Ministry as a national strategy to qualify health professionals, seeking to create tutorial apprenticeship teams in strategic fields for the Brazilian National Health System (SUS), this way integrating education, service, and community (Brasil, 2010).

\section{Competencies for health care}

The students' initial expectation towards 'what to do' in the program was related to the gains in professional technical autonomy and the dental practice focused on the treatment of the users' oral diseases.

"[...] as I arrived I expected a service-learning program where I would work a lot, lots of clinical work...That's what I wanted. I wanted to catch up with the speed of the work, that was my main objective, that's what I expected to happen". (Student 7)

This expectation was also perceived by the preceptors and the teachers who were doing the following them up along the program.

"[...] their concern in the beginning is to see the structure of the clinic, to see what it's like, to see if they will be able to do the dental care there, the time for the treatment, I believe all 
of this causes much concern, $[\ldots]$ I see that when they arrive their biggest expectation is to practice". (Preceptor 6)

The reduction of the individual to the treatment of teeth guides the social history of dentistry, the identity of the dentist, and the working process centered on the dental office. This is still the prevailing model in dental education and in people's minds (Emmerich, Castiel, 2009).

The widening of the concept of oral health and disease has brought along the necessity of understanding the user's needs in depth.

The preceptors' reports showed that students had difficulty in understanding the users and the determination of oral health and disease not only as a set of signs and symptoms restricted to the mouth.

"[...] when they (the students) arrive here, the first thing they want to do is to show that they know, but they try to speak in a very technical language to the patients, they speak in a language that the patients don't understand, they try to blame the patients for things, they arrive saying: 'you don't brush because you don't want to, you have toothpaste, you have water'...". (Preceptor 1)

Dental education cannot pertain only to the efficient search for evidences for the diagnosis, treatment, prognosis, etiology, and prophylaxis of diseases and the health hazards. It should, just as well, allow the development of cultural competency and sensitivity towards the health needs of people in the production of care.

\section{The development of bond with the community}

While practicing in primary health care, interacting with the team and the community, and recognizing themselves as workers of the health system, the students' initial perceptions were changing. The bond established among the students and the population deconstructed ideas that were presented in the beginning of this experience.

"[...] I believe that the simple fact of working and being there adds a new vision in every sense, coexisting with people, with other professionals outside from the university, the reality chock, caused by both the people and the work that is developed there and by all of this confrontation". (Student 7)

The bond is an instrument that promotes bonding commitments and co-responsibility amongst the professionals and the community (Pinheiro, Oliveira, 2011). This goes beyond the establishment of a simple contact with the population of a specific territory and a registration form. It demands closeness and commitment of the professional to the user's genuine needs.

"[...] you see a woman in early pregnancy and later you watch the baby grow and you follow up him, I feel it is much more gratifying. You can observe this relationship, get to know the families, visit their homes, I find this delightful, it's a way of working that provides more positive feedback". (Student 12)

\section{The humanization of dental health care}

Learning about the act of care was emphasized by the students when they referred to their participation in group activities and in a multiprofessional teamwork, and in a special way with community embracing. 
Service-learning produces the necessary subjectivity for the culture of care. The relational field is prioritized in this manner of working. Fostering the encounter with the users is encouraged (Franco, Merhy, 2011).

\footnotetext{
"In the university, we spend a whole semester without understanding why a patient doesn't collaborate, when we say something it seems as if he has understood, and when he returns it's all back to the same. The treatment does not progress because we don't know much about life". (Student 12)
}

Care is built through permanent reflection upon the relationship between the social meaning of diseases and the available technologies and services to overcome them (Ayres, 2004). This perception regarding care is neither immediate nor easy for the students.

It's a difficult and complex process for the students as well as for the preceptors and teachers. It means to break through the structured ways of working and find the world as it is, that is, with its setbacks e potentialities in the uniqueness in which they come to being.

\section{Final considerations}

Experiences of dental education in health services outside teaching institutions have been described in the literature (Eriksen et al., 2011; Piskorowski et al., 2011). The findings of this study have shown that service-learning in primary care services of SUS has impacted on the education of dentists, enhancing their competency in understanding and intervening with the reality faced by them. Learning about the way that health services work, the multiprofessional teamwork, and the development of competencies for autonomy in problem solving were evidenced.

The study demonstrated that service-learning represents a strategic pedagogical venue for education in health. However, the need for permanent questioning about the practices and the ensuring of qualified infrastructure and professionals for in health services was also noticed.

One of the major issues that the study found, concerning the impacts on dental education while experiencing community health services, was the establishment of bonds, autonomy in problem solving and multiprofessional teamwork. Learning how the health services work, about health care, and the development of cultural competence was evidenced.

The professional education accomplished by means of the experiences with communities in health services, such as the experience studied, should not be perceived as an 'additional' asset to the curricula, but much more as an integrating component of the contemporary dental curriculum. The students' opinions and perceptions must be taken into consideration in order to make this experience a successful one.

\section{Collaborators}

Ramona Fernanda Ceriotti Toassi led the research, taking responsibility for data collection and wrote all parts of the article. Alexandre Baumgarten held transcribing the interviews, collaborated in the interpretation of the categories and wrote the results/ discussion sections. Eloá Rossoni and Arisson Rocha da Rosa collaborated on the interpretation of categories and wrote the results/discussion sections. Cristine Maria Warmling and Sonia Blauth Slavutzky were responsible for the revision of the text and participated in the elaboration of the article. 


\section{References}

AYRES, J.R.C.M. O cuidado, os modos de ser (do humano) e as práticas de saúde. Saude Soc., v.13, n.3, p.16-29, 2004.

BARDIN, L. Análise de conteúdo. 70.ed. São Paulo: Almedina, 2011.

BRASIL. Portaria Interministerial no 421, de 3 de março de 2010. Institui o Programa de Educação pelo Trabalho para a Saúde (PET Saúde) e dá outras providências. Diário Oficial da União, Brasília, DF, 5 mar. 2010. Seção 1, p. 52.

Ministério do Trabalho e Emprego. Cartilha esclarecedora sobre a lei do estágio: lei no 11.788/2008. Dispõe sobre o estágio de estudantes. Brasília: MTE, SPPE, DPJ, CGPI, 2008.

Conselho Nacional de Educação. Câmara de Educação Superior. Resolução CNE/CES 3/2002, de 19 de fevereiro de 2002. Institui as Diretrizes Curriculares Nacionais do Curso de Graduação em Odontologia. Diário Oficial da União, Brasília, DF, 4 mar. 2002. Seção 1, p.10.

DAVIDSON, P.L. et al. Reforming dental workforce education and practice in the USA. Eur. J. Dent. Educ., v.15, n.2, p.73-9, 2011.

ELKIND, A. Outreach teaching: is this the future for dental education? Br. Dent. J., v.193, n.2, p.111-2, 2002.

EMMERICH, A.; CASTIEL, L. D. Jesus tem dentes metal-free no país de banguelas?: odontologia dos desejos e das vaidades. Hist. Cienc. Saude-Manguinhos, v.16, n.1, p.95-107, 2009.

ERIKSEN, H.M. et al. Evaluation of a dental outreach teaching programme. Eur. J. Dent. Educ., v.15, n.1, p.3-7, 2011.

FRANCO, T.B.; MERHY, E.E. El reconocimiento de la producción subjetiva del cuidado. Salud Colect., v.7, n.1, p.9-20, 2011.

HOLBROOK, W.P. et al. Balancing the role of the dental school in teaching, research and patient care; including care for underserved areas. Eur. J. Dent. Educ., v.12, n.1, p.161-6, 2008.

HOOD, J.G. Service-learning in dental education: meeting needs and challenges. J.

Dent. Educ., v.73, n.4, p.454-63, 2009.

JODELET, D. As representações sociais. Rio de Janeiro: UERJ, 2001.

KRESS JUNIOR, G.C. Dental education in transition. In: COHEN, L.K.; GIFT, H.C. (Orgs.). Disease prevention and oral health promotion social-dental sciences in action. Copenhagen: Munsksgaard, 1995. p.387-425.

MINAYO, M.C.S. O desafio do conhecimento: pesquisa qualitativa em saúde. 10.ed. São Paulo: Hucitec, 2007.

MORITA, M.C.; HADDAD, A.E.; ARAÚJO, M.E. Perfil atual e tendências do cirurgião-dentista brasileiro. Maringá: Dental Press International, 2010.

MOYSÉS, S.J. Políticas de saúde e formação de recursos humanos em Odontologia. Rev. ABENO, v.4, n.1, p.30-7, 2004.

OLIVEIRA, D.C. et al. A política pública de saúde brasileira: representação e memória social de profissionais. Cad. Saude Publica, v.24, n.1, p.197-206, 2008.

PINHEIRO, P.M.; OLIVEIRA, L.C. A contribuição do acolhimento e do vínculo na humanização da prática do cirurgião-dentista no Programa saúde da família. Interface (Botucatu), v.15, n.6, p.185-98, 2011.

PISKOROWSKI, W.A. et al. Development of a sustainable community-based dental education program. J. Dent. Educ., v.75, n.8, p.1038-43, 2011. 
POLYZOIS, I.; CLAFFEY, N.; MATTHEOS, N. Problem-based learning in academic health education. A systematic literature review. Eur. J. Dent. Educ., v.14, n.1, p.55-64, 2010.

PUCCA JUNIOR, G.A.; LUCENA, E.H.G.; CAWAHISA, P.T. Financing national policy on oral health in Brazil in the context of the Unified Health System. Braz. Oral Res., v.24, n.1, p.26-32, 2010.

SANTA-ROSA, T.T.A.; VARGAS, A.M.D.; FERREIRA, E.F. O internato rural e a formação de estudantes do curso de odontologia da UFMG. Interface (Botucatu), v.11, n.23, p.451-66, 2007.

SPINK, M.J.P. O conceito de representação social na abordagem psicossocial. Cad. Saude Publica, v.9, n.3, p.300-8, 1993.

STRAUSS, A.; CORBIN, J. Pesquisa qualitativa: técnicas e procedimentos para o desenvolvimento de teoria fundamentada. 2.ed. Porto Alegre: Artmed, 2008.

TOASSI, R.F.C. Atenção básica à saúde na educação superior e odontologia: o estágio curricular na Faculdade de Odontologia da UFRGS. 2011. Relatório final Edital FAPERGS no 01/2010 - Auxílio Recém Doutor (ARD), processo 10/0496-5. Porto Alegre, 2011.

TOASSI, R.F.C. et al. Currículo integrado no ensino de odontologia: novos sentidos para a formação na área da saúde. Interface (Botucatu), v.16, n.41, p.529-42, 2012.

WARMLING, C.M.; MARZOLA, N.R.; BOTAZZO, C. Da autonomia da boca: práticas curriculares e identidade profissional na emergência do ensino da odontologia brasileiro. Hist. Cienc. Saude-Manguinhos, v.19, n.1, p.181-95, 2012.

YIN, R.K. Estudo de caso: planejamentos e métodos. 4.ed. Porto Alegre: Bookman, 2010.

YODER, K.M. A framework for service-learning in dental education. J. Dent. Educ., v.70, n.2, p.115-23, 2006.

ZILBOVICIUS, C. et al. A paradigm shift in predoctoral dental curricula in Brazil: evaluating the process of change. J. Dent. Educ., v.75, n.4, p.557-64, 2011.

TOASSI, R.F.C. et al. La enseñanza en los servicios de atención primaria del sistema gubernamental de salud brasileño (SUS) en la formación de los profesionales de salud en Brasil. Interface (Botucatu), v.17, n.45, p.385-92, abr./jun. 2013.

El objetivo de este estudio fue el examen del papel de la enseñanza en los servicios de atención primaria del sistema gubernamental de salud brasileño (SUS) para la formación de los cirujanos-dentistas en una universidad pública del sur del Brasil. El enfoque metodológico fue cualitativo (estudio de caso) y se realizaron entrevistas con 12 estudiantes de Odontología, seis preceptores cirujanos-dentistas y tres profesores relacionados con el plan de estudios de prácticas curriculares. Los resultados mostraron que las prácticas curriculares en los servicios de atención primaria tienen impacto en la formación del cirujano-dentista mediante el establecimiento de vínculos, autonomía para resolución de problemas y trabajo en equipo multi-profesional. Hubo aprendizajes sobre el funcionamiento de los servicios de salud, cuidado en salud y el desarrollo de competencia cultural. Hay necesidad de cuestionamiento permanente de las prácticas y de asegurar infraestructura y profesionales calificados para la enseñanza en los servicios.

Palabras clave: Estudiantes de odontología. Servicios de salud. Atención primaria de salud. Currículo. Investigación cualitativa.

Recebido em 03/10/12. Aprovado em 29/04/13. 